\title{
Ing1 functions in DNA demethylation by directing Gadd45a to H3K4me3
}

\author{
Andrea Schäfer, ${ }^{1,3}$ Emil Karaulanov, ${ }^{1}$ Ulrike Stapf, ${ }^{1}$ Gabi Döderlein, ${ }^{2}$ and Christof Niehrs ${ }^{1,2,3}$ \\ ${ }^{1}$ Institute of Molecular Biology, 55128 Mainz, Germany; ${ }^{2}$ Division of Molecular Embryology, DKFZ-ZMBH Alliance, German \\ Cancer Research Center, 69120 Heidelberg, Germany
}

\begin{abstract}
Active DNA demethylation regulates epigenetic gene activation in numerous processes, but how the target site specificity of DNA demethylation is determined and what factors are involved are still poorly understood. Here we show that the tumor suppressor inhibitor of growth protein 1 (Ing1) is required for targeting active DNA demethylation. Ing1 functions by recruiting the regulator of DNA demethylation growth arrest and DNA damage protein 45a (Gadd45a) to histone $\mathrm{H} 3$ trimethylated at Lys 4 (H3K4me3). We show that reduced H3K4 methylation impairs recruitment of Gadd45a/Ing1 and gene-specific DNA demethylation. Our results indicate that histone methylation directs DNA demethylation.
\end{abstract}

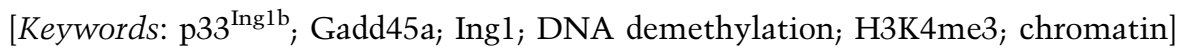

Supplemental material is available for this article.

Received January 9, 2012; revised version accepted December 26, 2012.

DNA methylation at 5-methylcytosine $(5 \mathrm{mC})$ of CpGs is a common epigenetic mark in metazoa, which plays important roles in regulating gene expression, genomic imprinting, X-chromosome inactivation, genomic instability, embryonic development, and cancer (Costello and Plass 2001; Jones and Takai 2001; Ehrlich 2005). It has become clear that DNA methylation is reversible by enzymatic "active" DNA demethylation, with examples in plants, animal development, cancer, and immune cells (for review, see Niehrs 2009; Zhu 2009; Schär and Fritsch 2011). However, the molecular mechanisms underlying active demethylation are only beginning to be understood.

In Arabidopsis, active DNA demethylation involves DNA base excision repair of methylated cytosines, mediated by the Demeter/ROS1 DNA glycosylase family (Choi et al. 2002; Gong et al. 2002; Gehring et al. 2006). In animal cells, various DNA repair-based mechanisms seem to mediate active demethylation involving base excision repair (Kangaspeska et al. 2008; Metivier et al. 2008; Rai et al. 2008; Bhutani et al. 2010; Cortazar et al. 2011; Cortellino et al. 2011) and/or methyl oxidation (Kriaucionis and Heintz 2009; Tahiliani et al. 2009; Guo et al. 2011; He et al. 2011). We showed that growth arrest and DNA damage protein 45a (Gadd45a) mediates active DNA demethylation (Barreto et al. 2007). Gadd45a is member of a small gene family of stress response genes encoding $18-\mathrm{kDa}$ acidic histone fold proteins (Zhan et al.

${ }^{3}$ Corresponding authors

E-mail a.schaefer@imb-mainz.de

E-mail c.niehrs@imb-mainz.de

Article is online at http://www.genesdev.org/cgi/doi/10.1101/gad.186916.112.
1994). Gadd45 proteins are multifunctional and regulate a range of cellular processes, including DNA repair, proliferation, apoptosis, and differentiation (Fornace et al. 1988; Kastan et al. 1992; Smith et al. 1996; Carrier et al. 1999; Harkin et al. 1999; Hollander and Fornace 2002; Zhan 2005). Gadd45a-mediated demethylation involves recruitment of the nucleotide excision repair (NER) (Barreto et al. 2007; Schmitz et al. 2009; Le May et al. 2010; Schäfer et al. 2010) and/or base excision repair (Rai et al. 2008; Cortellino et al. 2011) machineries (for review, see Niehrs and Schäfer 2012).

Gadd45a does not appear to affect global DNA demethylation (Jin et al. 2008; Engel et al. 2009; Schäfer et al. 2010). Instead, Gadd45 proteins function in gene-specific demethylation of target genes such as $r D N A$ in HEK293T cells (Schmitz et al. 2009); Bdnf IX and Fgf-1B during neurogenesis in the mouse brain (Ma et al. 2009); Bdnf IX in psychosis in the human brain (Gavin et al. 2011); reelin and $B d n f I X$ upon activation of glutamate receptors (Matrisciano et al. 2011); S100 during epidermal differentiation (Sen et al. 2010); CD11a and CD70 in T cells (Li et al. 2010); $R A R \beta 2$ following retinoic acid stimulation (Le May et al. 2010); osterix, Dlx5, Runx2, and BGP during bone differentiation (Zhang et al. 2011); and plasmid DNA in Xenopus oocytes and zebrafish embryos (Barreto et al. 2007; Rai et al. 2008). A common theme of these studies is that demethylation by Gadd45 is a highly selective process: Not only is it gene specific, but within a given gene, it typically affects distinct mCpGs, often in the promoter region. This specificity highlights a set of general, unresolved key questions in DNA demethylation: What determines the target site specificity of DNA 
demethylation? Is there a relationship between sitespecific DNA demethylation and the epigenetic landscape? What may be the cofactors involved?

Gadd45a is a nuclear protein but does not bind significantly to naked DNA (Carrier et al. 1999; Sytnikova et al. 2011), yet chromatin immunoprecipitation (ChIP) shows specific recruitment to demethylation sites (Barreto et al. 2007; Ma et al. 2009; Schmitz et al. 2009; Le May et al. 2010; Gavin et al. 2011), suggesting the involvement of cofactors. Gadd45a physically interacts with a number of DNA/chromatin-binding proteins, including nuclear hormone receptors (Yi et al. 2000), core histones (Carrier et al. 1999), PCNA (Smith et al. 1994), Taf12 (Schmitz et al. 2009), and p33 ${ }^{\text {ING1b }}$ (Cheung et al. 2001). In this study, we focused on $\mathrm{p} 33^{\text {ING1b }}$ (ING1b [inhibitor of growth 1b]) because it shares various properties with Gadd45a. ING1b is member of the ING (ING1 to ING5) family of tumor suppressors, most of which contain a conserved plant homeodomain (PHD) finger motif (Garkavtsev et al. 1996; Campos et al. 2004; for review, see Soliman and Riabowol 2007). Like Gadd45a, ING1 is induced by stress or UV irradiation, inhibits cell growth by interacting with p21 waf1, and promotes NER (Cheung et al. 2001). Furthermore, Ing1 mouse mutants are radiation-sensitive and tumor-prone, like Gadd45a mutants (Hollander et al. 1999; Kichina et al. 2006). ING proteins are found in complex with histone acetyl transferases (HATs) (Vieyra et al. 2002) and histone deacetylases (HDACs) (Skowyra et al. 2001; Kuzmichev et al. 2002). Important for this study, ING1 contains a PHD finger domain that specifically binds to histone $\mathrm{H} 3$ trimethylated at Lys 4 (H3K4me3) (Shi et al. 2006; Wysocka et al. 2006), suggesting that ING1 can read and translate the histone code (Shi et al. 2006; Pena et al. 2008).

We discovered that Ing1 is a novel factor required for gene-specific DNA demethylation. Gain- and loss-offunction experiments indicate that Ing1 functions during Gadd45a-mediated DNA demethylation. ChIP experiments and manipulation of cellular $\mathrm{H} 3 \mathrm{~K} 4 \mathrm{me} 3$ levels show that ING1b recruits GADD45a to the promoter of the cancer/testis antigen melanoma antigen gene B2 (MAGEB2). Genome-wide gain- and loss-of-function experiments identified additional target genes regulated synergistically by Gadd45a and Ing1 in a H3K4me3dependent fashion. Thus, this study describes a novel factor essential for DNA demethylation and indicates that histone methylation is required to direct DNA demethylation.

\section{Results}

\section{GADD45a requires ING1b for DNA demethylation}

We first analyzed whether GADD45a and ING1b biochemically interact. In coimmunoprecipitation (co-IP), endogenous GADD45a bound ING1 in HEK293T lysates (Fig. 1A). Using in vitro pull-downs, we mapped the GADD45a-binding domain to lie between the PHD and the partial bromodomain, a region without distinctive protein motifs (Supplemental Fig. S1A). We next established that Gadd45a and ING1b also functionally interact by performing luciferase assays using an in vitro methylated, SV4O-driven reporter plasmid. Gadd45a reactivates such methylation silenced reporters by DNA demethylation (Barreto et al. 2007; Schmitz et al. 2009; Hu et al. 2010). In cotransfection experiments, ING1b strongly enhanced reporter activation by Xenopus Gadd45a in a dose-dependent manner (Fig. 1B), and this was accompanied by DNA demethylation of the reporter (Fig. 1C). The ING1b domains required for Gadd45a functional interaction mapped to the $\mathrm{C}$ terminus, including the PHD domain (Fig. 1D). Also, a W235A point mutation, which disrupts the PHD domain (Pena et al. 2008), was inhibitory (Supplemental Fig. S1B). In loss-of-function experiments, siING1b abolished reporter gene activation (Fig. 1E; controlled in Supplemental Fig. S1C), while siRNA knockdown of another ING1 splice variant, $p 47^{I N G 1 a}($ ING1a), lacking the N-terminal PIP and partial bromodomain enhanced the reporter activation by Gadd45a (Fig. 1E).

Not only human ING1b, but also both mouse Ing1 proteins (p31 ${ }^{\text {Ing1a/c }}$ and p37 ${ }^{\text {Ing1b) }}$ (Zeremski et al. 1999; Kichina et al. 2006) synergized with mouse Gadd45a in reporter reactivation (Supplemental Fig. S1D,E). Furthermore, another reporter, Oct4TK-GFP, was synergistically activated by ING1b and human GADD45a (Fig. 1F). Bisulfite sequencing of the Oct4TK-GFP reporter confirmed site-specific DNA demethylation after GADD45a transfection, which was potentiated by ING1b (Fig. 1G). This effect was direct, as both proteins bound the reporter plasmid in ChIP experiments (Fig. 1H,I). Notably, GADD45a binding was significantly increased by ING1b expression (Fig. 1I), suggesting that ING1b enhances GADD45a recruitment to target reporters. Importantly, reporter binding of both ING1b and GADD45a was fully dependent on the ING1b-PHD domain, suggesting a targeting to chromatin, and, indeed, the reporter plasmid was chromatinized (Supplemental Fig. S1F,G).

These results indicate that (1) Gadd45a and ING1b biochemically and functionally interact in DNA demethylation; (2) ING1b-and in particular its chromatinbinding PHD domain-is required for the Gadd45amediated reactivation of methylation silenced reporters; and (3) the proteins directly bind to the demethylation substrate in a PHD domain-dependent manner.

\section{ING1b targets GADD45a to MAGEB2 demethylation sites}

By a candidate approach, we identified MAGEB2 as an endogenous demethylation target of GADD45a and ING1b. The expression of the gene family of cancer/ testis antigens is high in testis and silenced in somatic tissues but is activated due to DNA demethylation specifically in many invasive cancers (De Smet et al. 1996, 1999). $M A G E$ genes are promising targets for anti-tumor immunotherapy (Sang et al. 2011).

$M A G E B 2$ expression was inhibited by GADD45a or ING1b siRNAs in RKO cells (Fig. 2A; controlled in Supplemental Fig. S2A), and this was accompanied by 
A
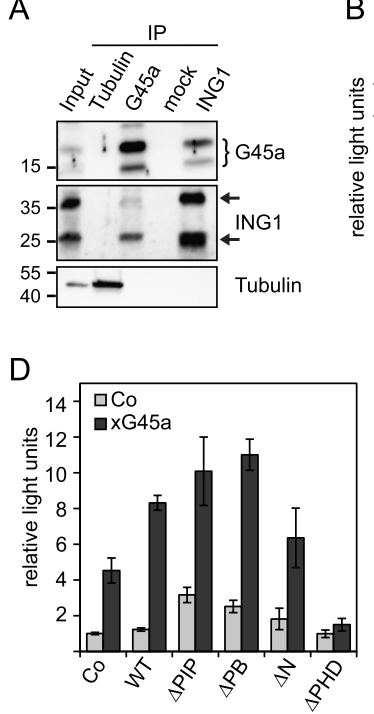

G
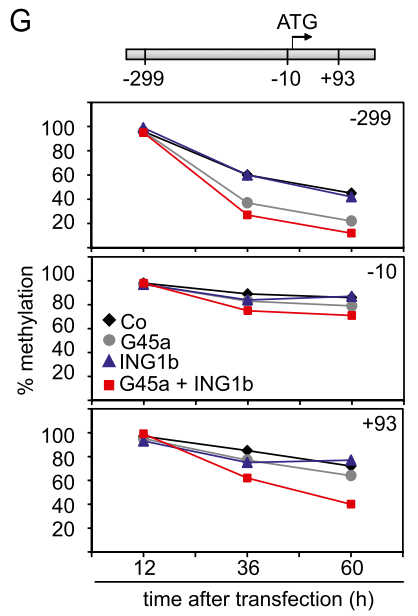

B

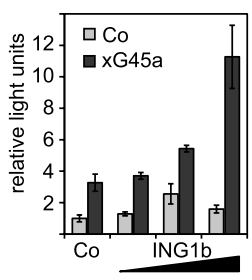

E

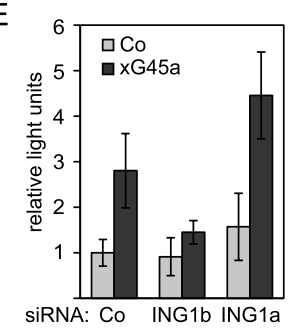

C
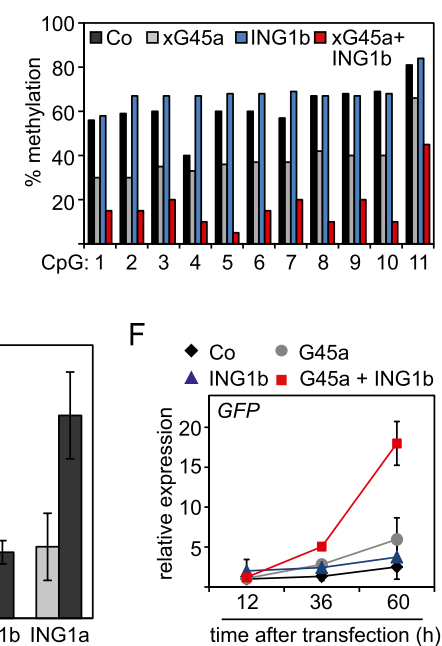

$\mathrm{H}$
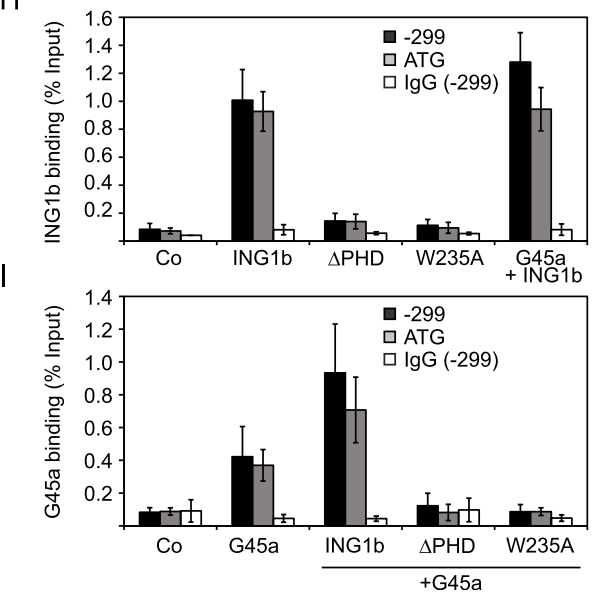

Figure 1. ING1b binds GADD45a and is required for DNA demethylation of methylated reporter plasmids. $(A)$ Co-IP and Western blot analysis of GADD45a and ING1 in HEK293T cells. Input shows $5 \%$ of lysates used for immunoprecipitation. $(B)$ Luciferase reporter assays of HEK293T cells transiently transfected with empty vector (Co) or Xenopus Gadd45a $(x G 45 a)$ and human $I N G 1 b$ along with in vitro methylated SV40 reporter plasmid. (C) DNA methylation analysis by 454 bisulfite sequencing of the luciferase reporter plasmid treated as in $B$. $(D, E)$ Luciferase reporter assays as in $B$ using $I N G 1 b$ deletion mutants $(D)$ (see scheme in Supplemental Fig. S1A) or the indicated siRNAs $(E) .(F, G)$ HEK293T cells transiently transfected with empty vector (Co), human HA-GADD45a, and myc-ING1b along with in vitro methylated Oct4TK-GFP reporter plasmid were analyzed for relative GFP expression monitored at the indicated time points after transfection by qPCR $(F)$ or DNA methylation of three CpGs $(-299,-10,+93)$ of the Oct4TK-GFP regulatory region by 454 bisulfite sequencing $(G)$. (H,I) ChIP of myc-ING1b $(H)$ or HAGADD45a (I) of two regions of the Oct4TK-GFP reporter spanning CpG -299 or the ATG (see scheme in G) using HEK293T chromatin (harvested $48 \mathrm{~h}$ after transfection) as described in $F$ and $G$. ChIP using IgG served as negative control. (ATG) Translation start site. Bar charts represent the mean of independent experiments $(n=3)$ with error bars as \pm standard deviation (SD). promoter hypermethylation (Fig. 2B). Specifically, the $M A G E B 2$ promoter was generally hypermethylated except for three adjacent CpGs located at $-70,-65$, and -57 , which were methylated only between $30 \%$ and $60 \%$, (Supplemental Fig. S2B). GADD45a or ING1b siRNAs led to hypermethylation of these three CpGs (Fig. 2B). Consistent with a direct effect, transfected epitope-tagged GADD45a bound the MAGEB2 locus, with the highest enrichment at the transcription start site, as did myc-ING1b (Supplemental Fig. S2C). Sequential re-ChIP assays confirmed that ING1b and GADD45a coassociate in the same chromatin fraction (Fig. 2C). Moreover, endogenous GADD45a also bound to the $M A G E B 25^{\prime}$ upstream region, and importantly, this binding was impaired by siING1b (Fig. 2D). ING1b binding, however, was not affected by depletion of GADD45a (Supplemental Fig. S2D). We conclude that (1) ING1b and GADD45a maintain hypomethylation of the MAGEB2 promoter and prevent gene silencing and (2) ING1b targets GADD45a to specific demethylation sites of MAGEB2.

\section{ING1b targets GADD45a to H3K4me3 via its PHD} domain

A hallmark of ING1b is its ability to read and translate H3K4me3 histone marks via its PHD domain. This suggests that Gadd45a-mediated DNA demethylation is targeted to $\mathrm{H} 3 \mathrm{~K} 4 \mathrm{me} 3$. Consistent with this, ING1b $\Delta \mathrm{PHD}$ and $\mathrm{ING}^{\mathrm{W}} \mathrm{b}^{\mathrm{W} 235 \mathrm{~A}}$ failed to synergize with Gadd45a in transcriptional activation of the methylated luciferase reporter (Fig. 1D; Supplemental Fig. S1B) and likewise impaired recruitment of Gadd45a to the Oct4TK-GFP reporter and its DNA demethylation (Fig. 1I; data not shown).

$\mathrm{H} 3 \mathrm{~K} 4 \mathrm{me} 3$ is commonly associated with the promoter regions of actively transcribed genes (Santos-Rosa et al. 2002; Schneider et al. 2004). As expected, H3K4me3 showed maximal occupancy around the transcription start site of MAGEB2 (Fig. 2E), overlapping with endogenous GADD45a binding. Sequential re-ChIP assays confirmed that GADD45a and ING1b both bind to chromatin occupied by H3K4me3 (Fig. 2F,G).

We performed pull-down assays using biotinylated histone peptides to confirm that Gadd45a can be recruited 
A

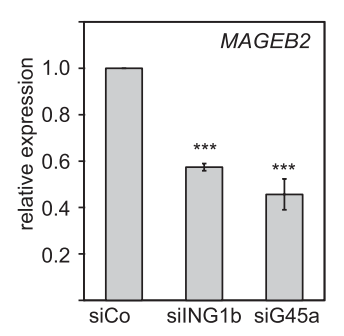

B

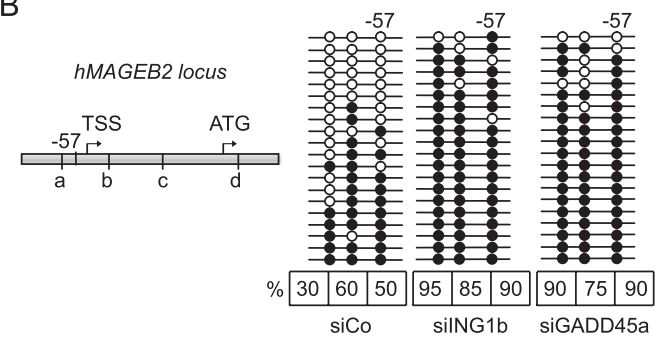

C

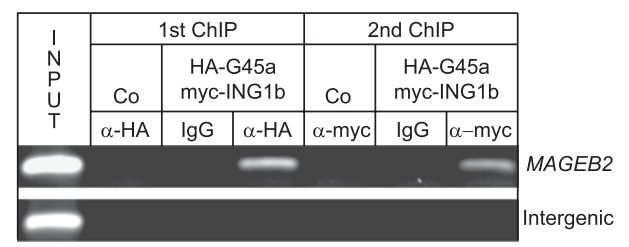

D

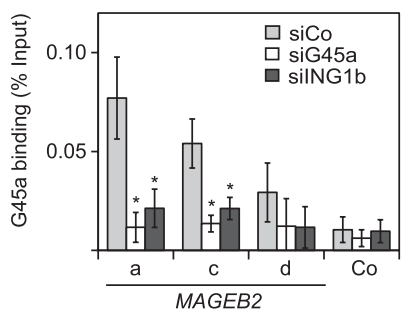

$E$

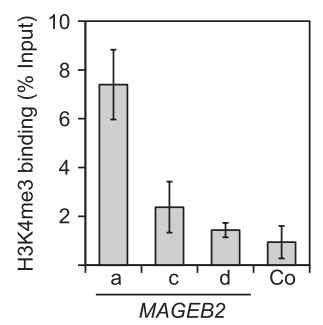

G

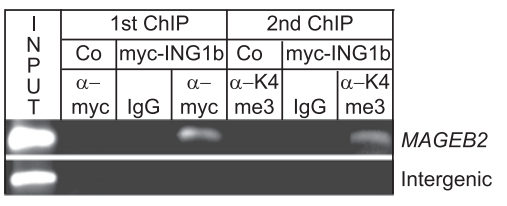

$\mathrm{F}$

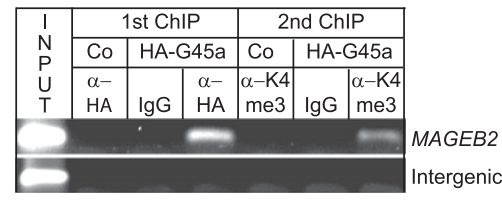

$\mathrm{H}$

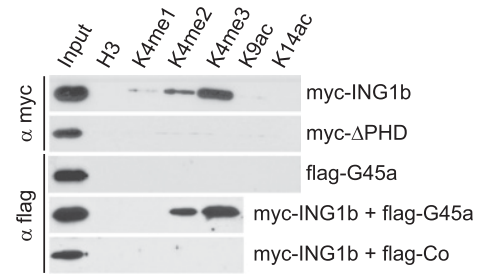

Figure 2. ING1b targets GADD45a to the $M A G E B 2$ demethylation site. $(A, B)$ RKO cells were transiently transfected for $48 \mathrm{~h}$ with control (Co), ING1b-specific, or GADD45aspecific siRNA. (A) Relative MAGEB2 expression analysis. $(B)$ Bisulfite sequencing analysis of genomic DNA of CpGs at $-70,-65$, and -57 relative to the MAGEB2 transcription start site. Each line represents one clone. White and black circles indicate unmethylated and methylated $\mathrm{CpG}$, respectively (for complete MAGEB2 promoter methylation profile, see Supplemental Fig. S2A). (Left) The diagram indicates the analyzed $\mathrm{CpG}$ at -57 and sites a-d used for ChIP analysis. (TSS) Transcription start sites; (ATG) translation start sites. $(C)$ Re-ChIP of RKO cells transfected with SMAD4 (Co) or HA-GADD45a and myc-ING1b. A second ChIP was performed on the precipitates of the first ChIP using the indicated antibodies. Material of the first and the second ChIP was used for PCR using primers specific for site a of MAGEB2 (see scheme in $B$ ) and for an intergenic control region (intergenic). $(D)$ Endogenous GADD45a ChIP of MAGEB2 regulatory regions marked in the scheme in $B$ in RKO cells treated as in $A$ and $B$. (Co) qPCR of an intergenic control region. IgG ChIP served as negative control (data not shown). Level of significance $\left({ }^{\star}\right)$ is indicated versus siControl for each region. (E) H3K4me3 ChIP of MAGEB2 regulatory regions marked in the scheme in $B$ in untreated RKO cells. $(F, G)$ H3K4me3 Re-ChIP of RKO cells transfected with SMAD4 (Co) and HA$G A D D 45 a$ (HA-G45a) (F) or myc-ING1b $(G)$ as described in $C$. $(H)$ Western blot analysis of in vitro pull-downs from nuclear extracts of HEK293T cells transiently transfected with the indicated constructs using biotinylated histone peptides carrying the indicated modifications. Bar charts represent the mean of independent experiments $(n=3)$ with error bars as \pm SD.

to $\mathrm{H} 3 \mathrm{~K} 4 \mathrm{me} 3$ via ING1b. GADD45a alone did not bind to any of the tested histone peptides. However, when coexpressed with ING1b, GADD45a bound to H3K4me2 and H3K4me3. Expectedly, ING1b alone also bound specifically to H3K4me3 and, with decreasing affinity, di- and monomethylated H3K4 (Fig. 2H; Supplemental Fig. S3A; Pena et al. 2008). Deletion of the PHD domain (ING1b $\Delta \mathrm{PHD}$ ) or W235A point mutation abolished binding to H3K4me3 and recruitment of Gadd45a (Fig. 2H, Supplemental Fig. S3B). Toward acetylated peptides (H3K9ac and H3K14ac), ING1b had no affinity, even though it contains a partial bromodomain (Fig. 2H). These results indicate that ING1b can recruit GADD45a to H3K4me3 via its PHD domain.

\section{Gadd45a and Ing1 mediate Mageb2 demethylation}

We next analyzed Mageb2 regulation genetically in primary mouse embryonic fibroblasts (MEFs), which we generated from mice single mutant (Hollander et al. 1999;
Kichina et al. 2006) or double mutant (double knockout [DKO]) (this study) for Gadd45a and Ing1. Gadd45a and Ing1 are UV-inducible stress response genes (Fornace et al. 1988; Hollander et al. 1999; Cheung et al. 2001). Consistent with this, Gadd45a was up-regulated in UVirradiated wild-type MEFs, as were Ing1 $a$ and Ing1c, two of the three highly related alternative transcripts encoded by the mouse Ing 1 locus (Fig. 3A; Supplemental Fig. S4A). UV irradiation also strongly induced expression of Mageb1-3 (gene expression average of the three highly similar mouse homologs to the single human $M A G E B 2)$ (Fig. 3B; De Backer et al. 1995). Importantly, Mageb1-3 induction was reduced in Gadd45a and Ing1 single-mutant MEFs and was almost abolished in DKO MEFs (Fig. 3C). UV irradiation also induced 25\% Mageb2 promoter demethylation (Fig. 3D,E, CpG sites a and b; schematic in Supplemental Fig. S4B). This demethylation was reduced in Gadd45a and Ing1 single-mutant MEFs and was abolished in DKO MEFs (Fig. 3E). These results indicate that Gadd45a and Ing1 are required for 
A

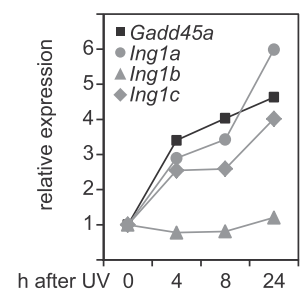

B

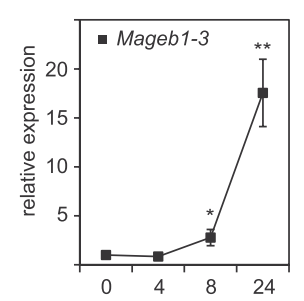

C

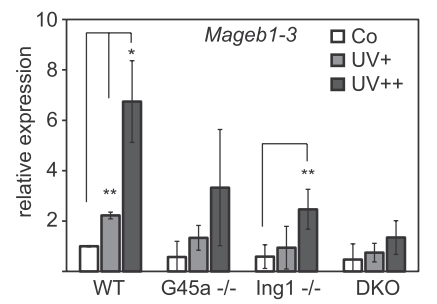

E
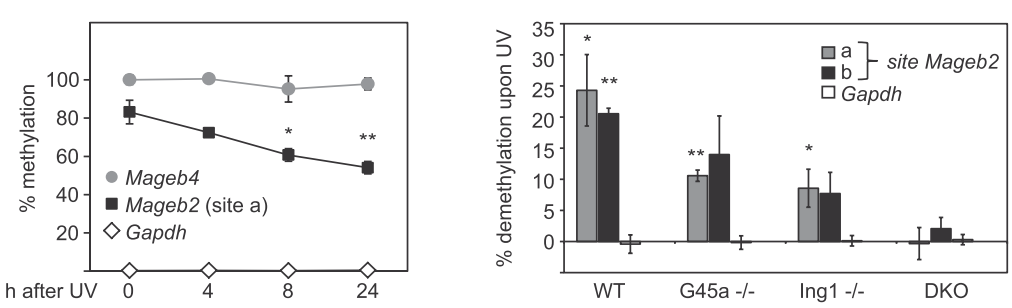

$\mathrm{F}$

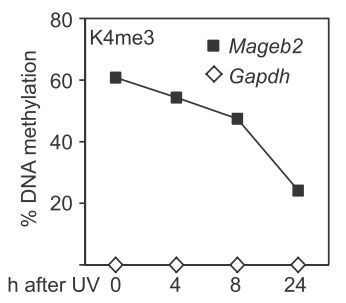

G

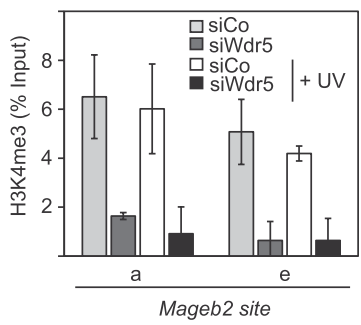

$\mathrm{H}$

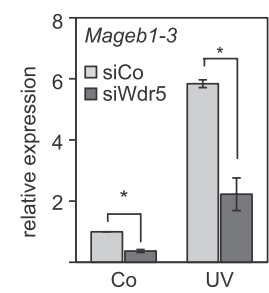

Figure 3. Gadd45a and Ing1 are required for UVinduced Mageb2 demethylation. $(A, B)$ Gene expression kinetics in MEFs irradiated at $t_{0}$ with 40 $\mathrm{J} / \mathrm{m}^{2}$. Relative expression was monitored by qPCR. (C) Mageb1-3 expression in MEFs irradiated with 20 or $40 \mathrm{~J} / \mathrm{m}^{2}(\mathrm{UV+}+++)$. Relative expression was monitored in the indicated mutant MEFs $16 \mathrm{~h}$ after treatment. $(D, E)$ Mageb2 promoter methylation in MEFs of the experiments shown in $B$ and $C(\mathrm{UV}++)$ monitored by methylation-sensitive qPCR. The Mageb2 sites ( $a$ and b) analyzed are indicated in Supplemental Figure S4B. (F) "ChIP-Chop" assay to determine the DNA methylation state of H3K4me3-occupied Mageb2 site a. UV-irradiated MEFs $\left(40 \mathrm{~J} / \mathrm{m}^{2}\right)$ were harvested at the indicated time points. After H3K4me3 ChIP, the immunoprecipitated DNA was subjected to methylation-sensitive restriction digest followed by PCR. $(G, H)$ MEFs were transiently transfected with the indicated siRNAs. After $36 \mathrm{~h}$, cells were UV-irradiated with $40 \mathrm{~J} / \mathrm{m}^{2}$ and analyzed after $16 \mathrm{~h}$. (G) H3K4me3 ChIP analysis of Mageb2 sites indicated in the scheme in Supplemental Figure S4B. $(H)$ Relative expression analysis of Mageb1-3. Bar charts represent the mean of independent experiments $(n=3)$ with error bars as \pm SD.
UV-induced activation and demethylation of Mageb2. Of note, the basal methylation level of Mageb2 increased from $80 \%$ to $100 \%$ in DKO MEFs (Supplemental Fig. S4C), suggesting that Gadd45a and Ing1 not only mediate UVinduced demethylation, but also protect the promoter from hypermethylation in steady state.

\section{H3K4me3 is required for Gadd45a/Ing1-induced Mageb2 demethylation}

We addressed whether Gadd45a/Ing1-mediated Mageb2 demethylation is targeted by H3K4me3 in MEFs. Despite its low expression level, uninduced Mageb2 was substantially bound by $\mathrm{H} 3 \mathrm{~K} 4 \mathrm{me}$, which was unaltered by UV treatment (Supplemental Fig. S5A). However, H3K4me3 chromatin was selectively demethylated: H3K4me3bound Mageb2 had 20\% reduced DNA methylation compared with input (60\% vs. $80 \%$ ) (Fig. 3F vs. D) and was preferentially demethylated following UV treatment $(20 \%$ vs. $60 \%$ ) (Fig. 3F vs. D). Consistent with H3K4me3 targeting demethylation, siRNA knockdown of Wdr5, an essential component of the MLL H3K4 methyltransferase (Milne et al. 2002; Wysocka et al. 2005), reduced global and Mageb2 promoter-associated H3K4me3 levels (Fig. 3G; Supplemental Fig. S5B) and, importantly, also impaired basal as well as UV-induced Mageb1-3 expression (Fig. 3H). Similarly, siWdr5 strongly impaired both Mageb1-3 expression and demethylation when triggered by GADD45a/ING1b overexpression instead of UV irradiation (Fig. 4A,B).

ChIP analysis showed that GADD45a and ING1b bound with a similar profile to the predicted Mageb2 transcription start site, encompassing the demethylation sites (Fig. 4C,D). Importantly, siWdr 5 impaired the binding of both proteins to Mageb2 (Fig. 4C,D). We conclude that WDR5-mediated H3K4 methylation is essential for GADD45a/ING1 to bind to the Mageb2 locus and promote gene activation by DNA demethylation.

\section{ING1b and GADD45a cooperate in gene activation and demethylation}

The above data support an interaction of Gadd45a and Ing1 in demethylation of reporter constructs and MAGEB2. To extend these findings, we performed genome-wide microarray profiling to analyze global changes in gene expression in HEK293T cells after expression of ING1b and GADD45a. If ING1b targets GADD45a in active DNA demethylation, then expression of both proteins should (1) activate rather than inhibit gene expression and (2) require the ING1b-PHD domain for synergism. Indeed, in the set of genes that showed a significant response only when GADD45a and ING1b were cotransfected, the majority were up-regulated ( 85 genes up-regulated vs. 24 genes down-regulated) (Fig. 5A; Supplemental Table S1). Individually, GADD45a and ING1b had only a modest 
Schäfer et al.

A

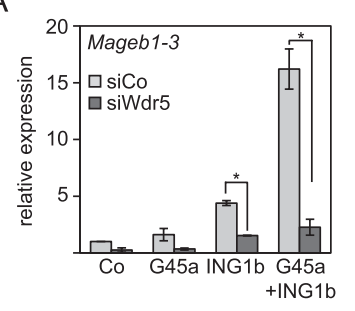

C

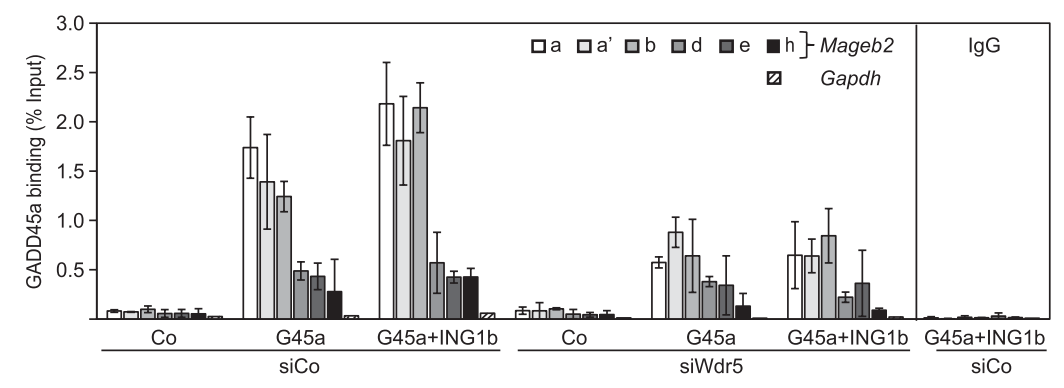

D

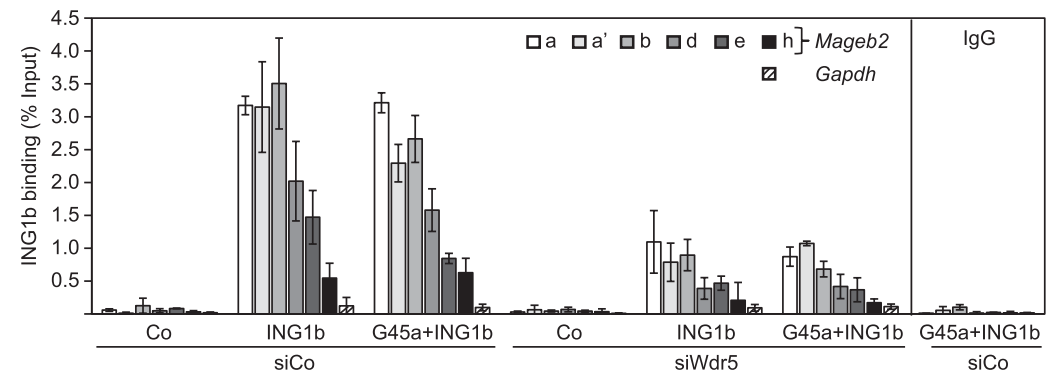

Figure 4. GADD45a/ING1b-induced demethylation of Mageb2 requires H3K4me3. (A) Relative Mageb1-3 expression in MEFs transiently transfected with the indicated siRNAs and retransfected with control DNA, HA-GADD45a, and myc-ING1b. (B) Methylation analysis of Mageb2 using genomic DNA of MEFs from the experiment described in $A$. Methylationsensitive qPCR assessing the sites $a, a^{\prime}$, and $b$ (see scheme in Supplemental Fig. S4B) and Gapdh. $(C, D)$ ChIP analysis of Mageb2 using chromatin of MEFs from the experiment in $A$ and $B .(C)$ HA-GADD 45a ChIP. $(D)$ myc-ING1b ChIP. Analyzed sites are indicated (see scheme Supplemental Fig. S4B). Bar charts represent the mean of independent experiments $(n=3)$ with error bars as \pm SD. impact on gene expression. Notably, GADD45a/ING1b cooperation was fully dependent on ING1b's PHD domain, as the deletion mutant did not cooperate with GADD45a in gene induction (Fig. 5B).

Examples of genes whose expression was synergistically induced by GADD45a and ING1b are DHRS2, FTCD, ARC, TCEAL7, VFG, and TAF7L, as validated by quantitative PCR (qPCR) (Fig. 5C). We exemplarily confirmed DNA demethylation of DHRS2 and TAF7L regulatory regions by GADD45a and ING1b, which once again was site-specific, affecting distinct CpGs (Fig. 5D,E). These results corroborate that ING1b and GADD45a synergistically act in gene activation and DNA demethylation.

\section{H3K4me3 directs GADD45a/ING1b to target sites}

We confirmed that recruitment of GADD45a/ING1b to some of the newly identified target genes involved H3K4me3. First, DNA demethylation and transcriptional activation of DHRS2 and TAF7L required the ING1b-PHD domain (Supplemental Fig. S6A-C). Second, in ChIP experiments, GADD45a and ING1b bound to the promoters of DHRS2, TCEAL7, and TAF7L in a ING1b-PHD domaindependent manner (Fig. 6A,B; Supplemental Fig. S6D). Third, siWDR5, which reduced H3K4me3 levels (Supplemental Fig. S6E), inhibited recruitment of transfected
ING1b and GADD45a (Fig. 6A,B). Importantly, endogenous ING1b/GADD45a also bound to DHRS2, TCEAL7, and $T A F 7 L$ regulatory regions, and this binding was reduced by siWDR5 as well (Fig. 6C-E). Moreover, while siING1b reduced GADD45a recruitment to DHRS2, TCEAL7, and TAF7L, siGADD45a did not affect endogenous ING1b binding to these target genes (Fig. 6D,E). We conclude that WDR5-mediated H3K4 methylation is essential for GADD45a/ING1b to bind to target promoters, confer demethylation, and promote gene activation.

\section{Ing1 and Gadd45a genetically interact in regulating gene expression}

To further corroborate the requirement of Ing1 and H3K4me3 in targeting Gadd45a-mediated demethylation, we carried out microarray expression profiling in MEFs deficient in Ing1, Gadd45a, or both (Supplemental Fig. S7A). The majority of affected genes showed differential expression only in DKO MEFs (135 genes up-regulated, and 145 genes down-regulated) (Fig. 7A; Supplemental Table S2). Differential expression of 12 genes was confirmed by qPCR and in two independent MEF lines (Fig. 7B; data not shown). These results corroborate that Gadd45a and Ing1 genetically interact in regulating gene expression. 
A

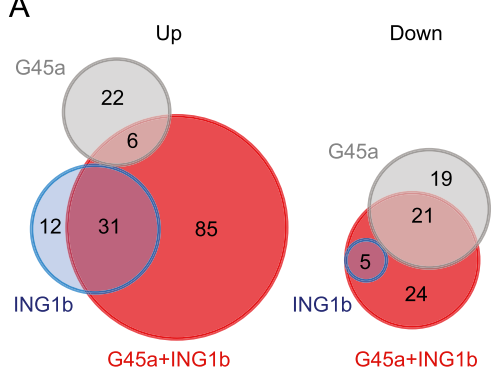

C

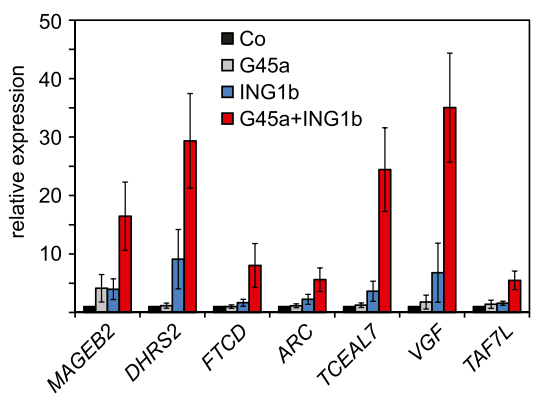

E

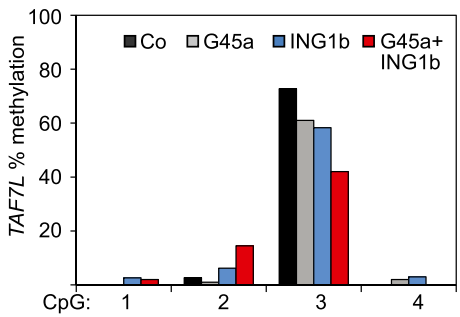

B

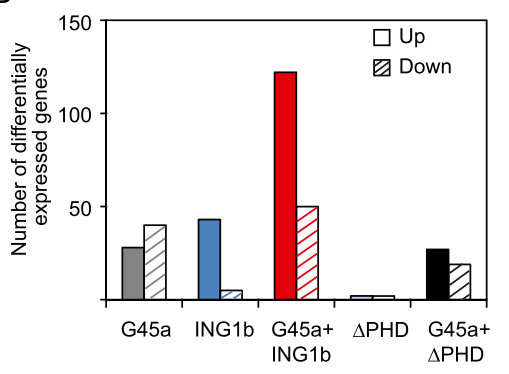

D

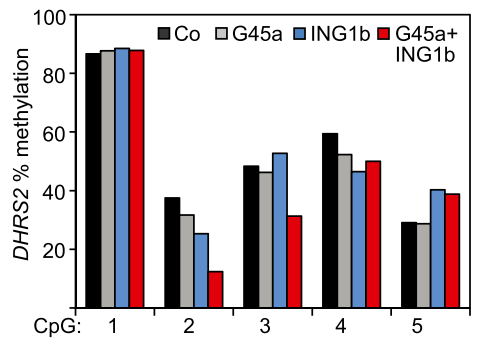

Figure 5. ING1b and GADD45a cooperate in gene activation and demethylation in gain of function. (A) Venn diagram showing differentially expressed genes (more than twofold) in HEK293T cells upon GADD45a (gray), ING1b (blue), or combined GADD45a/ING1b (red) expression compared with control transfected cells. (B) Statistics of differentially expressed genes as in $A$, including samples expressing ING1b $\Delta$ PHD or a combination of GADD45a/ ING1b $\Delta$ PHD. $(C)$ qPCR expression analysis of the indicated target genes in transiently transfected HEK293T cells. Bars show the mean of independent experiments $(n=8)$ with error bars as $\pm \mathrm{SD}$. $(D, E)$ DNA methylation analysis of the regulatory regions of DHRS2 $(D)$ and TAF7L $(E)$ in HEK293T cells treated as in $C$ assessed by 454 bisulfite sequencing.
Direct DNA demethylation target genes of Gadd45a/ Ing1 should be hypermethylated in DKOs and transcriptionally silenced. Gene class enrichment analysis of the DKO down-regulated genes revealed an overrepresentation of extracellular matrix components and proteins involved in immune response and development (Supplemental Table S3). For example, expression of the chemokine Cxcl1 and the homeobox gene Hoxd8 was strongly reduced in DKOs (Fig. 7B), and the majority of CpGs in their promoter region was hypermethylated, while few showed hypomethylation (Fig. 7C,D). Conversely, Cxcl1 and Hoxd8 were activated and bound at their promoters by transfected GADD45a and ING1b (Fig. 7E-G). Both recruitment to $\mathrm{Cxcl1}$ and $\mathrm{Hoxd} 8$ and activation by GADD45a and ING1b were inhibited by siWdr5 (Fig. 7E-H). siWdr5 also impaired basal expression of Cxcl1 and Hoxd8 (Supplemental Fig. S7B).

These results suggest that (1) endogenous Gadd45a/ Ing1 prevent silencing of $C x c 11$ and Hoxd8 by demethylating their regulatory regions and (2) Wdr5-mediated $\mathrm{H} 3 \mathrm{~K} 4 \mathrm{me} 3$ is required for this process. The evidence from both gain- and loss-of-function experiments therefore supports that the chromatin reader Ing1 recruits Gadd45a to DNA demethylation sites in a $\mathrm{H} 3 \mathrm{~K} 4 \mathrm{me} 3$-dependent manner.

\section{Discussion}

The proteins regulating DNA demethylation are mostly unknown. Here we demonstrate that the tumor suppressor Ingl is a novel factor involved in DNA demethylation. A major question concerning DNA demethylation is how the targeting to specific loci is regulated because it is essential for understanding how DNA methylation patterns are established, maintained, and remodeled. One main conclusion of this study is that Ing 1 serves as a cofactor that targets Gadd45a to specific loci by its ability to bind methylated H3K4 via its PHD domain. Thereby, it acts as an adapter between chromatin and Gadd45a, which in turn can recruit DNA repair enzymes capable of replacing 5mC (Barreto et al. 2007; Rai et al. 2008; Schmitz et al. 2009; Le May et al. 2010; Cortellino et al. 2011).

Our study therefore suggests a model (Supplemental Fig. S8) whereby histone methylation functions as one determinant for active DNA demethylation. The model fits the observation that the activating histone marks H3K4me2 and H3K4me3 are preferentially deposited around transcription start sites, similar to the distribution of Gadd45a and Ing1 at Mageb2 and other gene promoters (Barreto et al. 2007; Schmitz et al. 2009; Le May et al. 2010; 
Schäfer et al.

A

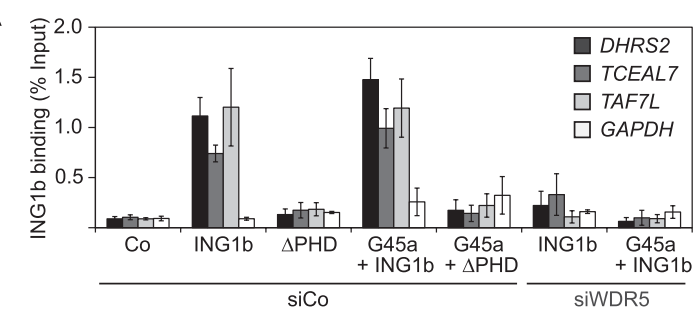

B

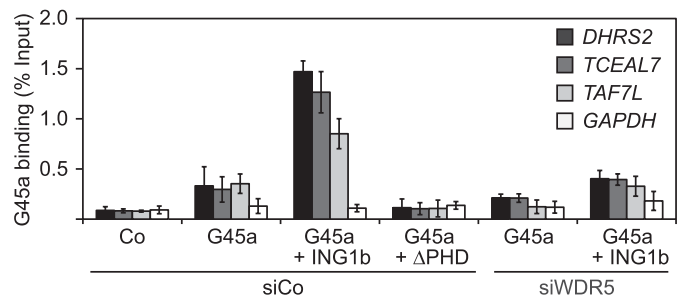

C
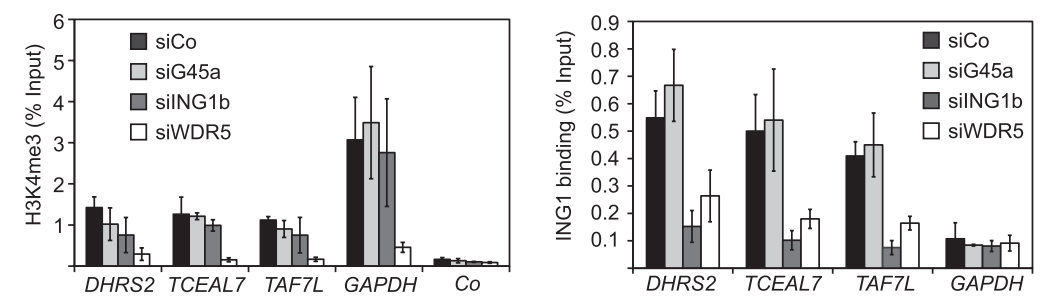

Figure 6. H3K4me3 targets GADD45a/ING1b. $(A, B)$ myc-ING1b ChIP $(A)$ (wild type or mutant) or HA-GADD45a ChIP $(B)$ of the regulatory regions of selected target genes, including the negative control region GAPDH. HEK293T cells were transiently transfected with the indicated siRNAs followed by DNA transfection of the indicated constructs. $(C-E) \mathrm{H} 3 \mathrm{~K} 4 \mathrm{me} 3(C)$, endogenous ING1 $(D)$, and endogenous GADD45a $(E)$ ChIP of the regulatory regions of selected target genes, including the negative control region GAPDH and an intergenic control region $(\mathrm{Co} ; C)$ in HEK293T cells. ChIP using IgG served as negative control (data not shown). Bar graphs represent the mean of independent experiments $(n=3)$ with error bars as $\pm \mathrm{SD}$.

E

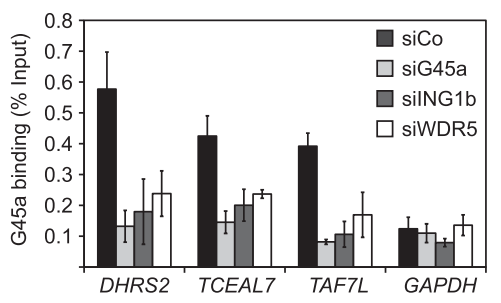

Cortellino et al. 2011). Also consistent with this, $\mathrm{H} 3 \mathrm{~K} 4 \mathrm{me} 2$ and H3K4me3 are strongly anti-correlated with 5mC (Okitsu and Hsieh 2007; Weber et al. 2007). However, while H3K4me3 is necessary, it is clearly not sufficient as a determinant for demethylation. H3K4me3 is present at many more loci than are regulated by DNA methylation. This was also observed for the Mageb2 promoter, which shows a broad H3K4me3 distribution, including at sites that are not demethylated (cf. Fig. 4B and Supplemental Fig. S5A). Indeed, another determinant for DNA demethylation appears to be low-level transcription (D'Alessio et al. 2007; Le May et al. 2010), and in the case of $r D N A$ promoter demethylation, this involves Gadd45a recruitment via Taf12 to RNA polymerase I (Schmitz et al. 2009). Another class of Gadd45-binding cofactors that may target demethylation are nuclear hormone receptors (Ito et al. 2007; Le May et al. 2010; Cortellino et al. 2011; Tian et al. 2011; Zhang et al. 2011). A further determinant may be the presence of $5 \mathrm{mC}$. For example, in Xenopus oocytes, Gadd45 engages excision repair on methylated but not unmethylated plasmid DNA, even though it binds to both (Barreto et al. 2007).

The fact that $\mathrm{H} 3 \mathrm{~K} 4 \mathrm{me} 3$ regulates DNA demethylation is in line with the reciprocal relationship between DNA methylation and histone modifications. For example, methylated DNA is bound by methyl-CpG-binding proteins that recruit histone methyltransferases to set repressive histone marks such as $\mathrm{H} 3 \mathrm{~K} 9$ me (Fujita et al. 1999|. Conversely, knockdown of the polycomb gene EZH2 or the repressive histone methyltransferases DIM-5 or kryptonite disrupt the DNA methylation pattern (Jackson et al. 2002; Tamaru and Selker 2003; Vire et al. 2006).

Finally, the results suggest that Gadd45a and Ing1 not only mediate UV-induced demethylation of Mageb2, but also protect its promoter from hypermethylation in steady state. Thus, even for steady-state methylation, there is an equilibrium, consistent with the notion that $5 \mathrm{mC}$ can undergo rapid turnover (Kangaspeska et al. 2008; Metivier et al. 2008).

The unanticipated role of the tumor suppressor Ing1 in DNA demethylation raises many new questions: What determines the site-specific demethylation of distinct mCpGs within a promoter covered by $\mathrm{H} 3 \mathrm{~K} 4 \mathrm{me} 3$ ? Which signaling cascades regulate Gadd45a/Ing1-mediated demethylation? How does their function in DNA demethylation relate to the biological processes in which Gadd45a/ Ing1 have been implicated, such as autoimmunity, aging, 
A

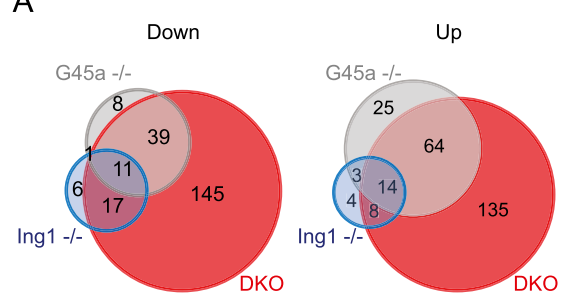

C

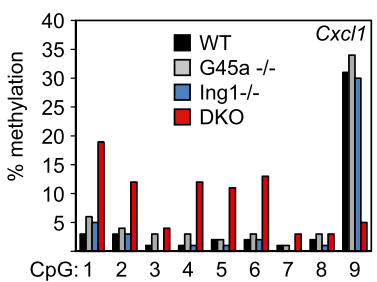

E

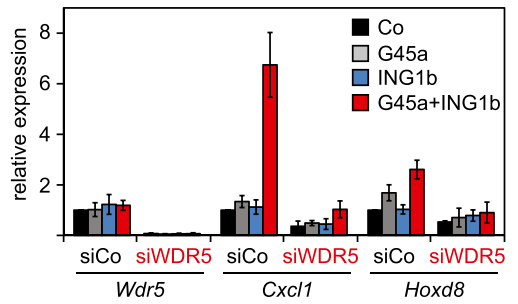

D
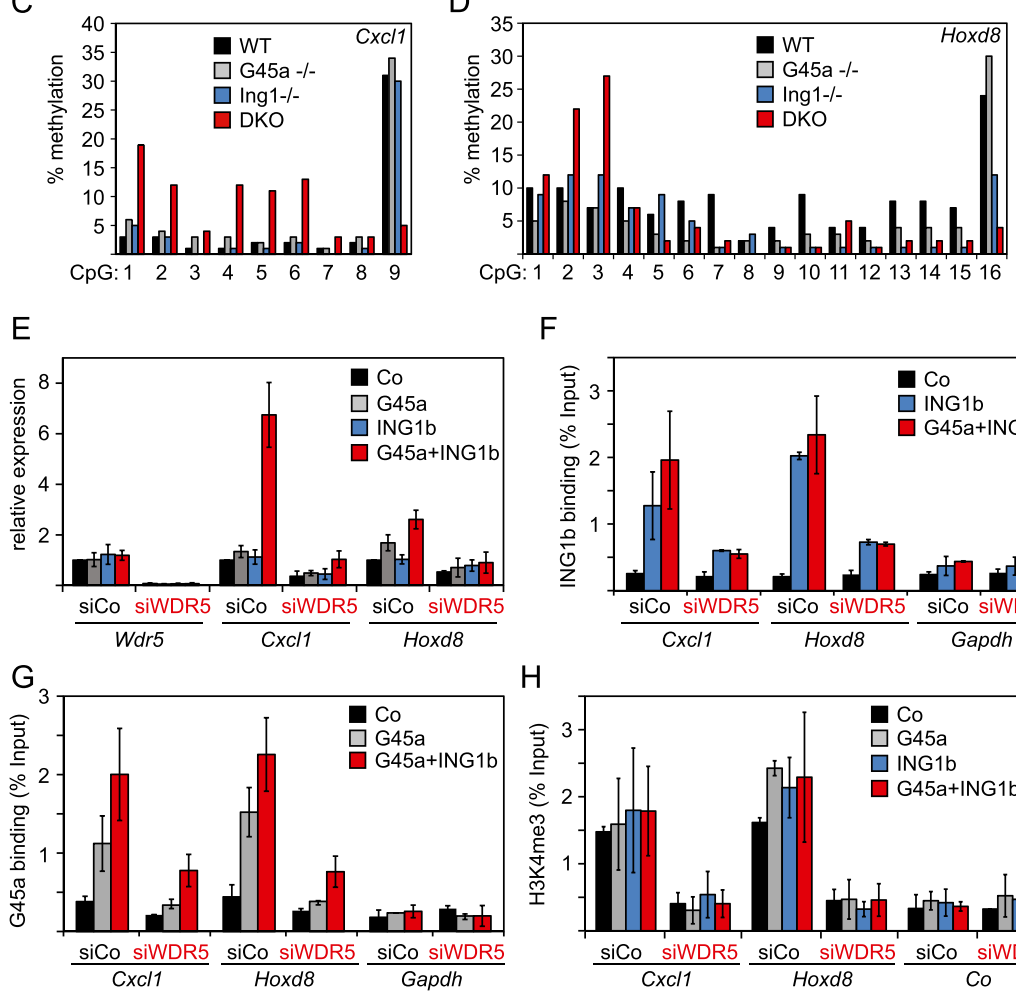

B

$\mathrm{F}$
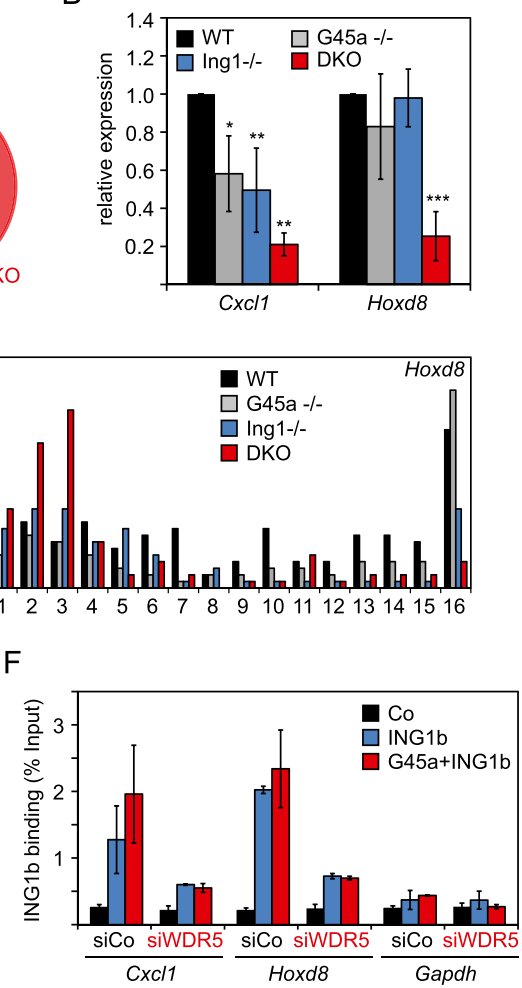

$\mathrm{H}$

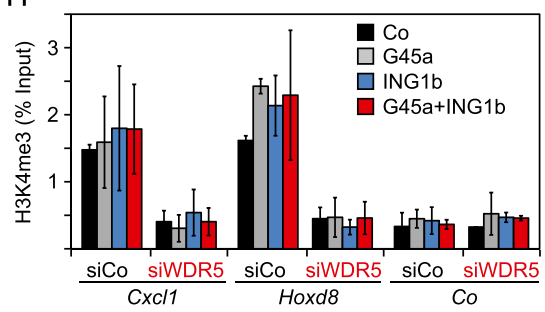

Figure 7. Ing1 and Gadd45a genetically interact in regulating gene expression. $(A)$ Venn diagram showing differentially expressed genes $(>1.5$-fold $)$ in $\mathrm{Gadd}_{45 a^{-1-}}$, Ing1 ${ }^{-1}$,- or DKO MEFs compared with wild-type (WT) MEFs. (B) qPCR expression analysis of Cxcl1 and Hoxd8 in MEFs of the indicated genotype. Bars represent the mean of independent experiments $(n=4)$ with error bars as $\pm S D$. $(C, D)$ DNA methylation analysis of the regulatory region of $C x c 11(C)$ and Hoxd8 $(D)$ in MEFs of the indicated genotype assessed by 454 bisulfite sequencing. $(E)$ qPCR expression analysis of the indicated genes in wild-type MEFs transiently transfected with the indicated siRNAs and retransfected with the indicated genes. $(F-H)$ ChIP for myc-ING1b $(F)$, HA-GADD45a $(G)$, and H3K4me3 $(H)$ of the regulatory regions of $C x c 11$ and Hoxd8, including either the negative control region Gapdh $(F, G)$ or an intergenic control region $(\mathrm{Co} ; H)$ in wild-type MEFs treated as described in E. Bars represent the mean of independent experiments $(n=3)$ with error bars as \pm SD. and cancer? These questions can now be addressed in mutant mice.

\section{Materials and methods}

\section{Tissue culture, transfection, and siRNA treatment}

HEK293T, RKO, and MEF cells were grown at $37^{\circ} \mathrm{C}$ in $10 \% \mathrm{CO}_{2}$ in Dulbecco's modified Eagle's medium (DMEM), 10\% fetal calf serum, $2 \mathrm{mM}$ L-glutamine, $100 \mathrm{U} / \mathrm{mL}$ penicillin, and $100 \mu \mathrm{g} / \mathrm{mL}$ streptomycin. MEFs were generated as described (Nagy et al. 2003) from embryonic day 15.5 embryos (Hollander et al. 1999; Kichina et al. 2006). Plasmid DNA was transfected using Fugene 6 (Fig. 1B-G) or X-tremeGENE 9 (Figs. 1H, 5, 6) (both from Roche) for HEK293T cells and Lipofectamine in combination with Plus reagent (Invitrogen) for RKO cells. Cells were transfected with $25 \mathrm{nM}$ GADD45a- or ING1a-specific Dharmacon siRNA Smart pools or $40 \mathrm{nM} W D R 5$-specific siRNA (Stealth, Invitrogen) using Lipofectamine 2000 (Invitrogen). For depletion of $I N G 1 b$, a selfdesigned Dharmacon siRNA was used: sense 5'-GGGAGAUC GACGCGAAUAUU-3'. For Figures 1E; 2, A, B, and D; and 6, A and B, HEK293T cells were incubated for $24 \mathrm{~h}$ with siRNA prior to plasmid DNA transfection. Similarly, MEFs were transfected with siRNA $24 \mathrm{~h}$ before plasmid DNA electroporation for
Figures 4 and 7, E-H. MEF electroporation was performed according to the manufacturers' instructions using $6 \mu \mathrm{g}$ of DNA and $10^{6}$ cells using the 100- $\mu$ L Tip Neon Transfection system (Invitrogen; $1250 \mathrm{~V}, 20 \mathrm{msec}$ ). For UV irradiation, MEF cells were washed with Hank's buffered salt solution, placed without liquid in a Stratalinker (Stratagene), and irradiated with 20 or $40 \mathrm{~J} / \mathrm{m}^{2}$ as indicated.

\section{Expression constructs and antibodies}

p3 $3{ }^{\text {ING1b }}$ wild-type and $\mathrm{p} 47^{\text {INGla }}$ cDNA were subcloned into pCS2-myc vector and used throughout the study. ING1b deletion constructs were generated by PCR. The W235A point mutation was introduced using the QuikChange II site-directed mutagenesis kit (Stratagene). The corresponding primers are listed in the Supplemental Material. Xenopus Flag-Gadd45aencoding and human HA-Gadd45a-encoding expression plasmids have been described (Barreto et al. 2007). Antibodies used were mouse $\alpha$ - $\alpha$-tubulin (Sigma); mouse $\alpha$-Flag M2 and rabbit (Western blot and ChIP) or mouse (immunoprecipitation) $\alpha$-Gadd45a and goat $\alpha$-ING1 (all from Santa Cruz Biotechnology); rabbit $\alpha-\mathrm{H} 3, \alpha-\mathrm{H} 3 \mathrm{~K} 4 \mathrm{me} 2, \alpha-\mathrm{H} 3 \mathrm{~K} 4 \mathrm{me} 3$, mouse $\alpha$-myc, rat $\alpha-\mathrm{HA}$, and IgG control (all from Abcam); or rabbit $\alpha-\mathrm{H} 3 \mathrm{~K} 4 \mathrm{mel}$ (Upstate Biotechnology). 


\section{Dual-luciferase reporter assay}

Dual-luciferase reporter assays (Promega) were performed as described (Barreto et al. 2007). In brief, HEK293T cells were transfected with $20 \mathrm{ng}$ of M.SssI in vitro methylated reporter and $5 \mathrm{ng}$ of effector, and for Figure 1B with 1, 5, or $10 \mathrm{ng}$ of $I N G 1 \mathrm{~b}$ in a 96-well plate format. Results are shown as the mean of triplicates \pm standard deviation $(\mathrm{SD})$.

\section{$R T-q P C R$}

Total RNA was isolated using a Qiagen RNeasy minikit with oncolumn DNase digest (Qiagen). First strand cDNA was generated using SuperScriptII reverse transcriptase (Invitrogen). Realtime PCR was performed in technical duplicates using Roche LightCycler480 probes master and primers in combination with predesigned monocolor hydrolysis probes of the Roche Universal Probe Library (UPL) (see the Supplemental Material). For quantification, Roche LC480 quantification software module was used. All values were normalized to the level of a housekeeping gene: GAPDH for human cells, or G6pd for MEF cells. Mean values shown were calculated using the mean value of the qPCR replicates from independent experiments $(n \geq 3)$.

\section{Microarray expression analysis}

HEK293T cells were transiently transfected in duplicates as described above and harvested $48 \mathrm{~h}$ after transfection. Male MEF cells were analyzed in duplicates derived from one MEF line per genotype. Total RNA was isolated using the RNeasy minikit with on-column DNase digest (Qiagen).

Microarray sample processing, hybridization, and scanning were performed on HumanHT-12 v4 and MouseWG-6 v2 expression BeadChips (Illumina) following the manufacturer's instructions. Data were processed, quality-controlled, and filtered with the GenomeStudio version 2011.1 software (Illumina) using the following parameters: background subtraction, cubic spline normalization, and Illumina custom error model with false discovery rate (FDR) multiple testing correction. Scored as differentially expressed were genes with FDR-adjusted differential $P$-values $<0.1$ and $>1.5$ (for the MEF experiment) or $>2.0$ (for the HEK293T experiment) thresholds for expression fold changes, which were calculated after flooring the normalized array signal intensities to 15 (equivalent to probe detection $P$-value of 0.1 ) in order to minimize the effect of random fluctuations in background noise. For the calculation of the number of differentially expressed genes in each sample, the most recent available manifest annotation files from Illumina were used, and some unassigned mouse array probes were further annotated using information from the MGI database (http://www.informatics.jax.org/batch). Downstream analysis of the filtered gene lists was carried out using DAVID (http://david.abcc.ncifcrf.gov), ToppGene (http:// toppgene.cchmc.org), BioVenn (http://www.cmbi.ru.nl/cdd/ biovenn), and Venny (http://bioinfogp.cnb.csic.es/tools/venny). The microarray data have been deposited in the NCBI's Gene Expression Omnibus (GEO) under accession number GSE43319 (http://www.ncbi.nlm.nih.gov/geo/query/acc.cgi?acc=GSE43319). For qPCR validation, the original samples were used as well as at least two additional experiments for MEF cells using two additional male lines per genotype.

\section{Analysis of DNA methylation}

For bisulfite sequencing, the regions of interest were PCRamplified from bisulfite-converted DNA (EpiTect kit, Qiagen) using Accuprime Taq polymerase (Invitrogen). For plasmid DNA bisulfite sequencing, the M.SssI- (Fig. 1C, pGL3-Luc) or HpaII (Fig. 1G, Oct4TK-GFP) in vitro methylated plasmid was recovered as described (Barreto et al. 2007) and linearized prior to bisulfite conversion (EpiTect kit, Qiagen).

Bisulfite sequencing of MAGEB2 was performed as described (Mund et al. 2005). The PCR products were purified by agarose gel electrophoresis, subcloned into TA-cloning vector pCR2.1 (Invitrogen), and sequenced. Bisulfite treatment efficiency and specificity were controlled using an unmethylated or in vitro methylated plasmid carrying the MAGEB2 promoter amplicon (data not shown).

For Figures 1C; 5, D and E; and 7, C and D, the PCR amplicons were ligated to Roche Multiplex Identifier (MID) adaptors, mixed, and analyzed using the Roche 454 GS Junior system. Only amplicons with $>100$ reads per sample were considered reliable.

For OctTK-GFP 454 sequencing, the primers were fused to Roche Titanium Adaptor sequences for amplification. The four samples of Figure 1G were analyzed in four lanes of the Roche GS FLX system and multiplexed for the three time points using Roche multiplex identifiers.

For methylation-sensitive PCR (MS-PCR), genomic DNA was digested with PvuII (control) or MS restriction enzyme. MS enzymes were HpaII for mouse Mageb2 site b, HhaI for mouse Mageb2 sites a and a' (see scheme in Supplemental Fig. S4B), and HpyCH4IV for mouse Mageb4. Methylation in percent was determined by qPCR from the ratio of digested versus control digested DNA for the respective CpGs. In ChIP-Chop assays, immunoprecipitated chromatin was subjected to the same procedure. The control promoter mouse Gapdh contained both a HpaII and a HhaI restriction site and was always unmethylated. Gapdh methylation based on HhaI restriction is shown in Figures 3, D-F, and 4B. All methylation analysis primers are listed in the Supplemental Material.

\section{Co-IP and ChIP}

For co-IP, HEK293T cells were lysed in $150 \mathrm{mM} \mathrm{NaCl}, 20 \mathrm{mM}$ Tris (pH 7.5), 2 mM EDTA, $10 \%$ glycerol, $1 \%$ Triton $\mathrm{X}-100$, and $1 \mathrm{mM} \beta$-mercaptoethanol containing Complete Mini Protease Inhibitor Cocktail (Roche). The lysates were syringe and needlehomogenized and cleared by centrifugation and by incubation with mixed protein $\mathrm{A} / \mathrm{G}$ agarose beads (50\% each; Roche) for $30 \mathrm{~min}$ at $4^{\circ} \mathrm{C}$. Lysates were directly used for immunoprecipitation without the freezing step $\left(\sim 4 \times 10^{6}\right.$ cells per immunoprecipitation). After antibody incubation overnight at $4^{\circ} \mathrm{C}$ on a rotating wheel, protein $\mathrm{A} / \mathrm{G}$ agarose beads were added for $1 \mathrm{~h}, 30 \mathrm{~min}$. Beads were washed four times using the immunoprecipitation lysis buffer and eluted with $4 \times$ Laemmli buffer containing $10 \%$ $\beta$-mercaptoethanol. For Western blot analysis, one-third of the eluate was loaded along with $5 \%$ of the input lysate.

RKO ChIP was performed essentially as described (Wells et al. 2002) using a mixture of protein $\mathrm{A} / \mathrm{G}$ agarose beads (Roche). For re-ChIP, chromatin was eluted with $50 \mathrm{mM}$ Tris $(\mathrm{pH} 8.0), 1 \%$ SDS, and $10 \mathrm{mM}$ EDTA. Ninety percent of the eluate was subjected to a second immunoprecipitation after a 20 -fold dilution in ChIP dilution buffer (1.1\% Triton, 1.2 mM EDTA, 16.7 $\mathrm{mM}$ Tris-Cl at $\mathrm{pH} 8.2,167 \mathrm{mM} \mathrm{NaCl}$ ).

Chromatin isolation and ChIP of HEK293T and MEF cells was also performed as described (Wells et al. 2002) with some modifications. For immunoprecipitation, a mixture of protein A/G Dynabeads (Invitrogen) was incubated with $20 \mu \mathrm{g}$ of chromatin (tagged proteins) or $120 \mu \mathrm{g}$ of chromatin (endogenous proteins, freshly used without the freezing step). After incubation with the chromatin, the beads were washed five times using the above-described co-IP buffer. After elution with 50 
$\mathrm{mM}$ Tris (pH 8.0), 1\% SDS, and $10 \mathrm{mM}$ EDTA overnight at $65^{\circ} \mathrm{C}$, proteinase $\mathrm{K}$ digestion for $2 \mathrm{~h}$ at $56^{\circ} \mathrm{C}$, and purification via QIAquick PCR purification columns (Qiagen), samples were used for qPCR.

Mean values shown in the graphs were calculated using the mean value of the qPCR replicates from independent experiments $(n \geq 3)$.

\section{In vitro pull-down assay}

For histone peptide-binding assays, biotinylated histone peptides were used (Upstate Biotechnology). Briefly, $0.2 \mu \mathrm{g}$ of peptide was incubated with $15 \mu \mathrm{L}$ of streptavidin Dynabeads (Dynal) in binding buffer $(50 \mathrm{mM}$ Tris- $\mathrm{HCl}$ at $\mathrm{pH} 8.0,150 \mathrm{mM} \mathrm{NaCl}$, $0.2 \%$ Triton X-100, $1 \mathrm{mM}$ dithiothreitol [DTT], EDTA-free Protease inhibitor cocktail [Roche]) for $45 \mathrm{~min}$ at $4^{\circ} \mathrm{C}$. After two washes, beads were added to $100 \mu \mathrm{g}$ of nuclear protein extracts expressing the indicated tagged proteins. After $3 \mathrm{~h}$ of incubation at $4^{\circ} \mathrm{C}$ in binding buffer, beads were washed five times using wash buffer $(20 \mathrm{mM}$ HEPES at $\mathrm{pH} 7.9,250 \mathrm{mM} \mathrm{KCl}, 0.2 \%$ Triton X-100, $1 \mathrm{mM}$ DTT, protease inhibitors) and subjected to Western blot analysis.

\section{Statistical analyses}

Data are expressed as mean values \pm SD of independent biological replicates $(n \geq 3)$. Two-tailed, unpaired Student's $t$-test was used to calculate the level of significance. A $P$-value of $<0.05$ was considered significant. $\left(^{\star}\right) P<0.05$; $\left(^{\star \star}\right) P<0.01$; $\left({ }^{\star \star \star}\right) P<0.001$.

\section{Acknowledgments}

We thank C. Hollander for providing Gadd45a mutant mice, and K. Riabowol and M. Whitman for reagents. We acknowledge the support of M. Gierl, the services of the DKFZ and IMB core facilities, and in particular the help of B. Korn, J. Müller, and S. Henze. This work was supported by an ERC senior investigator grant to C.N. ("DNA Demethylase").

\section{References}

Barreto G, Schäfer A, Marhold J, Stach D, Swaminathan SK, Handa V, Doderlein G, Maltry N, Wu W, Lyko F, et al. 2007. Gadd45a promotes epigenetic gene activation by repairmediated DNA demethylation. Nature 445: 671-675.

Bhutani N, Brady JJ, Damian M, Sacco A, Corbel SY, Blau HM. 2010. Reprogramming towards pluripotency requires AIDdependent DNA demethylation. Nature 463: 1042-1047.

Campos EI, Chin MY, Kuo WH, Li G. 2004. Biological functions of the ING family tumor suppressors. Cell Mol Life Sci 61: 2597-2613.

Carrier F, Georgel PT, Pourquier P, Blake M, Kontny HU, Antinore MJ, Gariboldi M, Myers TG, Weinstein JN, Pommier Y, et al. 1999. Gadd45, a p53-responsive stress protein, modifies DNA accessibility on damaged chromatin. Mol Cell Biol 19: 1673-1685.

Cheung KJ Jr, Mitchell D, Lin P, Li G. 2001. The tumor suppressor candidate p33(ING1) mediates repair of UV-damaged DNA. Cancer Res 61: 4974-4977.

Choi Y, Gehring M, Johnson L, Hannon M, Harada JJ, Goldberg RB, Jacobsen SE, Fischer RL. 2002. DEMETER, a DNA glycosylase domain protein, is required for endosperm gene imprinting and seed viability in Arabidopsis. Cell 110: 33-42.

Cortazar D, Kunz C, Selfridge J, Lettieri T, Saito Y, MacDougall E, Wirz A, Schuermann D, Jacobs AL, Siegrist F, et al. 2011.
Embryonic lethal phenotype reveals a function of TDG in maintaining epigenetic stability. Nature 470: 419-423.

Cortellino S, Xu J, Sannai M, Moore R, Caretti E, Cigliano A, Le Coz M, Devarajan K, Wessels A, Soprano D, et al. 2011. Thymine DNA glycosylase is essential for active DNA demethylation by linked deamination-base excision repair. Cell 146: 67-79.

Costello JF, Plass C. 2001. Methylation matters. J Med Genet 38: 285-303.

D'Alessio AC, Weaver IC, Szyf M. 2007. Acetylation-induced transcription is required for active DNA demethylation in methylation-silenced genes. Mol Cell Biol 27: 7462-7474.

De Backer O, Verheyden AM, Martin B, Godelaine D, De Plaen E, Brasseur R, Avner P, Boon T. 1995. Structure, chromosomal location, and expression pattern of three mouse genes homologous to the human MAGE genes. Genomics 28: 74-83.

De Smet C, De Backer O, Faraoni I, Lurquin C, Brasseur F, Boon T. 1996. The activation of human gene MAGE-1 in tumor cells is correlated with genome-wide demethylation. Proc Nat1 Acad Sci 93: 7149-7153.

De Smet C, Lurquin C, Lethe B, Martelange V, Boon T. 1999. DNA methylation is the primary silencing mechanism for a set of germ line- and tumor-specific genes with a CpG-rich promoter. Mol Cell Biol 19: 7327-7335.

Ehrlich M. 2005. The controversial denouement of vertebrate DNA methylation research. Biochemistry 70: 568-575.

Engel N, Tront JS, Erinle T, Nguyen N, Latham KE, Sapienza C, Hoffman B, Liebermann DA. 2009. Conserved DNA methylation in Gadd45a $\mathrm{a}^{-1-}$ mice. Epigenetics 4: 98-99.

Fornace AJ Jr, Alamo I Jr, Hollander MC. 1988. DNA damageinducible transcripts in mammalian cells. Proc Natl Acad Sci 85: 8800-8804.

Fujita N, Takebayashi S, Okumura K, Kudo S, Chiba T, Saya H, Nakao M. 1999. Methylation-mediated transcriptional silencing in euchromatin by methyl-CpG binding protein MBD1 isoforms. Mol Cell Biol 19: 6415-6426.

Garkavtsev I, Kazarov A, Gudkov A, Riabowol K. 1996. Suppression of the novel growth inhibitor p33ING1 promotes neoplastic transformation. Nat Genet 14: 415-420.

Gavin DP, Sharma RP, Chase KA, Matrisciano F, Dong E, Guidotti A. 2011. Growth arrest and DNA-damage-inducible, $\beta$ (GADD45b)-mediated DNA demethylation in major psychosis. Neuropsychopharmacology 37: 531-542.

Gehring M, Huh JH, Hsieh TF, Penterman J, Choi Y, Harada JJ, Goldberg RB, Fischer RL. 2006. DEMETER DNA glycosylase establishes MEDEA polycomb gene self-imprinting by allelespecific demethylation. Cell 124: 495-506.

Gong Z, Morales-Ruiz T, Ariza RR, Roldan-Arjona T, David L, Zhu JK. 2002. ROS1, a repressor of transcriptional gene silencing in Arabidopsis, encodes a DNA glycosylase/lyase. Cell 111: 803-814.

Guo JU, Su Y, Zhong C, Ming GL, Song H. 2011. Hydroxylation of 5-methylcytosine by TET1 promotes active DNA demethylation in the adult brain. Cell 145: 423-434.

Harkin DP, Bean JM, Miklos D, Song YH, Truong VB, Englert C, Christians FC, Ellisen LW, Maheswaran S, Oliner JD, et al. 1999. Induction of GADD45 and JNK/SAPK-dependent apoptosis following inducible expression of BRCA1. Cell 97: 575-586.

He YF, Li BZ, Li Z, Liu P, Wang Y, Tang Q, Ding J, Jia Y, Chen Z, Li L, et al. 2011. Tet-mediated formation of 5-carboxylcytosine and its excision by TDG in mammalian DNA. Science 333: 1303-1307.

Hollander MC, Fornace AJ Jr. 2002. Genomic instability, centrosome amplification, cell cycle checkpoints and Gadd45a. Oncogene 21: 6228-6233. 
Hollander MC, Sheikh MS, Bulavin DV, Lundgren K, AugeriHenmueller L, Shehee R, Molinaro TA, Kim KE, Tolosa E, Ashwell JD, et al. 1999. Genomic instability in Gadd45adeficient mice. Nat Genet 23: 176-184.

Hu XV, Rodrigues TM, Tao H, Baker RK, Miraglia L, Orth AP, Lyons GE, Schultz PG, Wu X. 2010. Identification of RING finger protein 4 (RNF4) as a modulator of DNA demethylation through a functional genomics screen. Proc Natl Acad Sci 107: 15087-15092.

Ito S, Kuraoka I, Chymkowitch P, Compe E, Takedachi A, Ishigami C, Coin F, Egly JM, Tanaka K. 2007. XPG stabilizes $\mathrm{TFIIH}$, allowing transactivation of nuclear receptors: Implications for Cockayne syndrome in XP-G/CS patients. Mol Cell 26: 231-243.

Jackson JP, Lindroth AM, Cao X, Jacobsen SE. 2002. Control of CpNpG DNA methylation by the KRYPTONITE histone H3 methyltransferase. Nature 416: 556-560.

Jin S, Guo C, Pfeifer G. 2008. GADD45A does not promote DNA demethylation. PLoS Genet 4: 1-9.

Jones PA, Takai D. 2001. The role of DNA methylation in mammalian epigenetics. Science 293: 1068-1070.

Kangaspeska S, Stride B, Metivier R, Polycarpou-Schwarz M, Ibberson D, Carmouche RP, Benes V, Gannon F, Reid G. 2008. Transient cyclical methylation of promoter DNA. Nature 452: 112-115.

Kastan MB, Zhan Q, el-Deiry WS, Carrier F, Jacks T, Walsh WV, Plunkett BS, Vogelstein B, Fornace AJ Jr. 1992. A mammalian cell cycle checkpoint pathway utilizing p53 and GADD45 is defective in ataxia-telangiectasia. Cell 71: 587-597.

Kichina JV, Zeremski M, Aris L, Gurova KV, Walker E, Franks R, Nikitin AY, Kiyokawa H, Gudkov AV. 2006. Targeted disruption of the mouse ing1 locus results in reduced body size, hypersensitivity to radiation and elevated incidence of lymphomas. Oncogene 25: 857-866.

Kriaucionis S, Heintz N. 2009. The nuclear DNA base 5hydroxymethylcytosine is present in Purkinje neurons and the brain. Science 324: 929-930.

Kuzmichev A, Zhang Y, Erdjument-Bromage H, Tempst P, Reinberg D. 2002. Role of the Sin3-histone deacetylase complex in growth regulation by the candidate tumor suppressor p33(ING1). Mol Cell Biol 22: 835-848.

Le May N, Mota-Fernandes D, Velez-Cruz R, Iltis I, Biard D, Egly JM. 2010. NER factors are recruited to active promoters and facilitate chromatin modification for transcription in the absence of exogenous genotoxic attack. Mol Cell 38: 54-66.

Li Y, Zhao M, Yin H, Gao F, Wu X, Luo Y, Zhao S, Zhang X, Su $\mathrm{Y}, \mathrm{Hu} \mathrm{N}$, et al. 2010. Overexpression of the growth arrest and DNA damage-induced $45 \alpha$ gene contributes to autoimmunity by promoting DNA demethylation in lupus $\mathrm{T}$ cells. Arthritis Rheum 62: 1438-1447.

Ma DK, Jang MH, Guo JU, Kitabatake Y, Chang ML, PowAnpongkul N, Flavell RA, Lu B, Ming GL, Song H. 2009. Neuronal activity-induced Gadd45b promotes epigenetic DNA demethylation and adult neurogenesis. Science 323: 1074-1077.

Matrisciano F, Dong E, Gavin DP, Nicoletti F, Guidotti A. 2011. Activation of group II metabotropic glutamate receptors promotes DNA demethylation in the mouse brain. Mol Pharmacol 80: 174-182.

Metivier R, Gallais R, Tiffoche C, Le Peron C, Jurkowska RZ, Carmouche RP, Ibberson D, Barath P, Demay F, Reid G, et al. 2008. Cyclical DNA methylation of a transcriptionally active promoter. Nature 452: 45-50.

Milne TA, Briggs SD, Brock HW, Martin ME, Gibbs D, Allis CD, Hess JL. 2002. MLL targets SET domain methyltransferase activity to Hox gene promoters. Mol Cell 10: 1107-1117.
Mund C, Beier V, Bewerunge P, Dahms M, Lyko F, Hoheisel JD. 2005. Array-based analysis of genomic DNA methylation patterns of the tumour suppressor gene p16INK4A promoter in colon carcinoma cell lines. Nucleic Acids Res 33: e73.

Nagy A, Gertsenstein M, Vintersten K, Behringer R. 2003. Manipulating the mouse embryo: A laboratory manual, 3rd ed. Cold Spring Harbor Laboratory Press, Cold Spring Harbor, NY.

Niehrs C. 2009. Active DNA demethylation and DNA repair. Differentiation 77: 1-11.

Niehrs C, Schäfer A. 2012. Active DNA demethylation by Gadd45 and DNA repair. Trends Cell Biol 22: 220-227.

Okitsu CY, Hsieh CL. 2007. DNA methylation dictates histone H3K4 methylation. Mol Cell Biol 27: 2746-2757.

Pena PV, Hom RA, Hung T, Lin H, Kuo AJ, Wong RP, Subach OM, Champagne KS, Zhao R, Verkhusha VV, et al. 2008. Histone H3K4me3 binding is required for the DNA repair and apoptotic activities of ING1 tumor suppressor. J Mol Biol 380: $303-312$.

Rai K, Huggins IJ, James SR, Karpf AR, Jones DA, Cairns BR. 2008. DNA demethylation in zebrafish involves the coupling of a deaminase, a glycosylase, and gadd45. Cell 135: 12011212.

Sang M, Lian Y, Zhou X, Shan B. 2011. MAGE-A family: Attractive targets for cancer immunotherapy. Vaccine 29: 8496-8500.

Santos-Rosa H, Schneider R, Bannister AJ, Sherriff J, Bernstein BE, Emre NC, Schreiber SL, Mellor J, Kouzarides T. 2002. Active genes are tri-methylated at $\mathrm{K} 4$ of histone H3. Nature 419: 407-411.

Schäfer A, Schomacher L, Barreto G, Doderlein G, Niehrs C. 2010. Gemcitabine functions epigenetically by inhibiting repair mediated DNA demethylation. PLOS ONE 5: e14060.

Schär P, Fritsch O. 2011. DNA repair and the control of DNA methylation. Prog Drug Res 67: 51-68.

Schmitz KM, Schmitt N, Hoffmann-Rohrer U, Schäfer A, Grummt I, Mayer C. 2009. TAF12 recruits Gadd45a and the nucleotide excision repair complex to the promoter of rRNA genes leading to active DNA demethylation. Mol Cell 33: 344-353.

Schneider R, Bannister AJ, Myers FA, Thorne AW, CraneRobinson C, Kouzarides T. 2004. Histone H3 lysine 4 methylation patterns in higher eukaryotic genes. Nat Cell Biol 6: 73-77.

Sen GL, Reuter JA, Webster DE, Zhu L, Khavari PA. 2010. DNMT1 maintains progenitor function in self-renewing somatic tissue. Nature 463: 563-567.

Shi $\mathrm{X}$, Hong $\mathrm{T}$, Walter KL, Ewalt M, Michishita E, Hung T, Carney D, Pena P, Lan F, Kaadige MR, et al. 2006. ING2 PHD domain links histone $\mathrm{H} 3$ lysine 4 methylation to active gene repression. Nature 442: 96-99.

Skowyra D, Zeremski M, Neznanov N, Li M, Choi Y, Uesugi M, Hauser CA, Gu W, Gudkov AV, Qin J. 2001. Differential association of products of alternative transcripts of the candidate tumor suppressor ING1 with the mSin3/HDAC1 transcriptional corepressor complex. I Biol Chem 276: 8734-8739.

Smith ML, Chen IT, Zhan Q, Bae I, Chen CY, Gilmer TM, Kastan MB, O'Connor PM, Fornace AJ Jr. 1994. Interaction of the p53-regulated protein Gadd45 with proliferating cell nuclear antigen. Science 266: 1376-1380.

Smith ML, Kontny HU, Zhan Q, Sreenath A, O'Connor PM, Fornace AJ Jr. 1996. Antisense GADD45 expression results in decreased DNA repair and sensitizes cells to u.v.-irradiation or cisplatin. Oncogene 13: 2255-2263. 
Soliman MA, Riabowol K. 2007. After a decade of study-ING, a PHD for a versatile family of proteins. Trends Biochem Sci 32: 509-519.

Sytnikova YA, Kubarenko AV, Schäfer A, Weber AN, Niehrs C. 2011. Gadd45a is an RNA binding protein and is localized in nuclear speckles. PLOS ONE 6: e14500.

Tahiliani M, Koh KP, Shen Y, Pastor WA, Bandukwala H, Brudno Y, Agarwal S, Iyer LM, Liu DR, Aravind L, et al. 2009. Conversion of 5-methylcytosine to 5-hydroxymethylcytosine in mammalian DNA by MLL partner TET1. Science 324: 930-935.

Tamaru H, Selker EU. 2003. Synthesis of signals for de novo DNA methylation in Neurospora crassa. Mol Cell Biol 23: 2379-2394.

Tian J, Huang H, Hoffman B, Liebermann DA, Ledda-Columbano GM, Columbano A, Locker J. 2011. Gadd $45 \beta$ is an inducible coactivator of transcription that facilitates rapid liver growth in mice. J Clin Invest 121: 4491-4502.

Vieyra D, Loewith R, Scott M, Bonnefin P, Boisvert FM, Cheema P, Pastyryeva S, Meijer M, Johnston RN, Bazett-Jones DP, et al. 2002. Human ING1 proteins differentially regulate histone acetylation. J Biol Chem 277: 29832-29839.

Vire E, Brenner C, Deplus R, Blanchon L, Fraga M, Didelot C, Morey L, Van Eynde A, Bernard D, Vanderwinden JM, et al. 2006. The Polycomb group protein EZH2 directly controls DNA methylation. Nature 439: 871-874.

Weber M, Hellmann I, Stadler MB, Ramos L, Paabo S, Rebhan M, Schubeler D. 2007. Distribution, silencing potential and evolutionary impact of promoter DNA methylation in the human genome. Nat Genet 39: 457-466.

Wells J, Graveel CR, Bartley SM, Madore SJ, Farnham PJ. 2002. The identification of E2F1-specific target genes. Proc Natl Acad Sci 99: 3890-3895.

Wysocka J, Swigut T, Milne TA, Dou Y, Zhang X, Burlingame $\mathrm{AL}$, Roeder RG, Brivanlou AH, Allis CD. 2005. WDR5 associates with histone $\mathrm{H} 3$ methylated at $\mathrm{K} 4$ and is essential for H3 K4 methylation and vertebrate development. Cell 121: 859-872.

Wysocka J, Swigut T, Xiao H, Milne TA, Kwon SY, Landry J, Kauer M, Tackett AJ, Chait BT, Badenhorst P, et al. 2006. A PHD finger of NURF couples histone $\mathrm{H} 3$ lysine 4 trimethylation with chromatin remodelling. Nature 442: 86-90.

Yi YW, Kim D, Jung N, Hong SS, Lee HS, Bae I. 2000. Gadd45 family proteins are coactivators of nuclear hormone receptors. Biochem Biophys Res Commun 272: 193-198.

Zeremski M, Hill JE, Kwek SS, Grigorian IA, Gurova KV, Garkavtsev IV, Diatchenko L, Koonin EV, Gudkov AV. 1999. Structure and regulation of the mouse ing1 gene. Three alternative transcripts encode two PHD finger proteins that have opposite effects on p53 function. J Biol Chem 274: 32172-32181.

Zhan Q. 2005. Gadd45a, a p53- and BRCA1-regulated stress protein, in cellular response to DNA damage. Mutat Res 569: 133-143.

Zhan Q, Lord KA, Alamo I Jr, Hollander MC, Carrier F, Ron D, Kohn KW, Hoffman B, Liebermann DA, Fornace AJ Jr. 1994. The gadd and MyD genes define a novel set of mammalian genes encoding acidic proteins that synergistically suppress cell growth. Mol Cell Biol 14: 2361-2371.

Zhang RP, Shao JZ, Xiang LX. 2011. GADD45A protein plays an essential role in active DNA demethylation during terminal osteogenic differentiation of adipose-derived mesenchymal stem cells. J Biol Chem 286: 41083-41094.

Zhu JK. 2009. Active DNA demethylation mediated by DNA glycosylases. Annu Rev Genet 43: 143-166. 


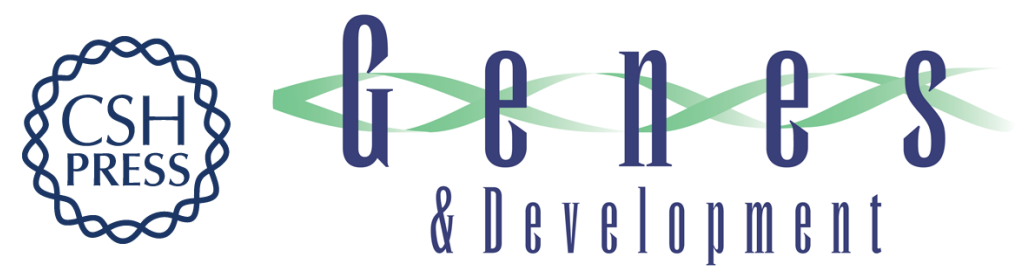

\section{Ing1 functions in DNA demethylation by directing Gadd45a to H3K4me3}

Andrea Schäfer, Emil Karaulanov, Ulrike Stapf, et al.

Genes Dev. 2013, 27:

Access the most recent version at doi:10.1101/gad.186916.112

\section{Supplemental http://genesdev.cshlp.org/content/suppl/2013/02/06/27.3.261.DC1 Material}

References This article cites 76 articles, 25 of which can be accessed free at: http://genesdev.cshlp.org/content/27/3/261.full.html\#ref-list-1

\section{License}

Email Alerting

Receive free email alerts when new articles cite this article - sign up in the box at the top Service 